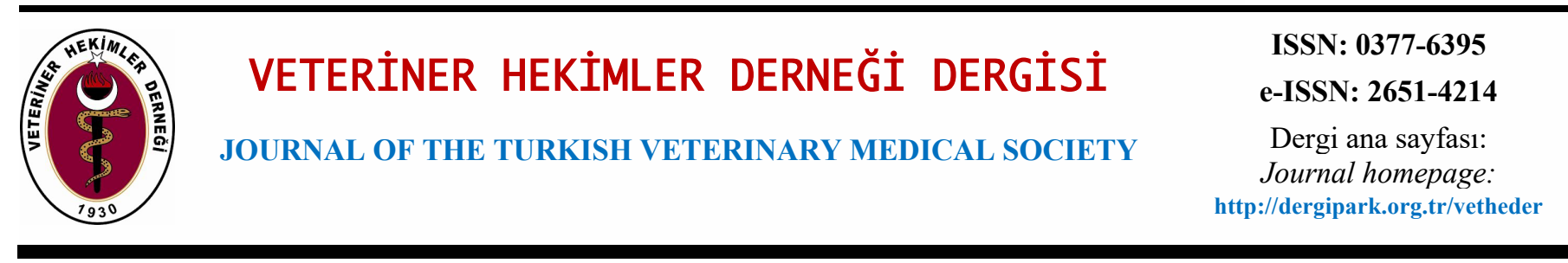

DOI: $10.33188 /$ vetheder.771696

Araştırma Makalesi / Research Article

\title{
The effect of heat stress on total oxidant capacity in hair goats
}

\author{
Serdal KURT ${ }^{1, a^{*}, \text { Funda EŞKI I }}{ }^{2, b}$, Seçkin SALAR ${ }^{3, c}$, Tevhide SEL ${ }^{4, d}$, Ayhan BAŞTAN ${ }^{3, e}$ \\ ${ }^{1}$ Dicle University, Faculty of Veterinary Medicine, Department of Obstetrics and Gynecology, 21280, Diyarbakur, Turkey \\ ${ }^{2}$ Cukurova University, Faculty of Ceyhan Veterinary Medicine, Department of Obstetrics and Gynecology, 01330 Adana, Turkey \\ ${ }^{3}$ Ankara University, Faculty of Veterinary Medicine, Department of Obstetrics and Gynecology, 06110, Ankara, Turkey \\ ${ }^{4}$ Ankara University, Faculty of Veterinary Medicine, Department of Biochemistry, 06110, Ankara, Turkey \\ ORCID: 0000-0002-0191-3245 ${ }^{a}$; 0000-0002-9242-927 $1^{b}$;0000-0001-9303-6253 ${ }^{c}$;0000-0002-9753-779X ${ }^{d}$;0000-0001-8291-114 $7^{e}$
}

\begin{abstract}
MAKALE BILGISI /
ARTICLE

INFORMATION:

Geliş / Received:

20 Temmuz 20

20 July 20
\end{abstract}

Kabul / Accepted:

09 Kasım 20

09 November 20

Keywords:

Altitude

Hair Goat

Heat Stress

Total oxidant capacity

Anahtar Sözcükler:

Is1 stresi

Kı1 keçisi

Rakım

Toplam oksidan

kapasitesi
ABSTRACT:

The aim of this study was to investigate the effect of heat stress on total oxidant capacity (TOC) in hair goats of different ages grown at different altitudes in the same season. The study was carried out on 208 hair goats ( 25 male and 183 female) in 11 different districts of Adana province (Turkey) in the summer season. The districts were grouped as 0-99 m (Group 1), 100-500 $\mathrm{m}$ (Group 2) and higher than $500 \mathrm{~m}$ (Group 3) according to altitude characteristics, and goats were classified into two groups as under 3 years and 4 years or older. Blood samples were collected, serums harvested and stored at $20^{\circ} \mathrm{C}$ until TOC analysis. Heat stress was determined according to the temperature humidity index (THI). There were severe and moderate heat stress in groups 1 and 2, respectively $(\mathrm{P}<0.001)$. TOC was significantly lower in group 2 compared to the other groups $(\mathrm{P}<0.001)$. The highest TOC was measured in group $3(\mathrm{P}<0.001)$. And TOC was significantly higher in animals aged 4 and older compared to under 3 years of age $(\mathrm{P}<0.05)$. Although male goats were exposed to significantly higher THI than female goats $(\mathrm{P}<0.01)$, TOC levels were found similar in both groups $(\mathrm{P}>0.05)$. In conclusion, altitude, THI, age and gender had a complex effect on TOC.

\section{Kıl keçilerinde usı stresinin toplam oksidan kapasitesine etkisi \\ ÖZET:}

Bu çalıșmanın amacı, aynı sezonda farklı rakımlarda yetiștirilen farklı yaştaki kıl keçilerinde ısı stresinin toplam oksidan kapasite (TOC) üzerindeki etkisini araştırmaktı. Çalışmada Türkiye, Adana'nın 11 farklı ilçesinden 25 erkek 183 dişi olmak üzere 208 keçi kullanıldı. İlçeler rakım özelliklerine göre 0-99 m (Grup 1), 100-500 m (Grup 2) ve 500 m'den daha yüksek (Grup 3) olmak üzere gruplandırıldı. Keçiler ise 3 yaşından küçük ve 4 yaş ya da daha yaşlı olarak iki gruba ayrıldı. Kan örnekleri alınarak serumları çıkarıldı ve TOC analizine kadar $-20^{\circ} \mathrm{C}^{\prime}$ de saklandı. Isı stresi sıcaklık nem indeksine (THI) göre belirlendi. Grup 1 ve 2'de sırasıyla şiddetli ve orta dereceli 1sı stresi vardı $(\mathrm{P}<0.001)$. TOC diğer gruplara göre grup 2'de anlamlı olarak düşük bulundu $(\mathrm{P}<0.001)$. En yüksek TOC grup 3 'te ölçüldü $(\mathrm{P}<0.001)$ ve TOC değeri 4 yaş ve üzerindeki hayvanlarda 3 yaşın altındakilere göre anlamlı derecede yüksekti $(P<0.05)$. Erkek keçiler dişi keçilerden anlamlı derecede daha yüksek THI'ye maruz kalmalarına rağmen $(\mathrm{P}<0.01)$, TOC seviyeleri benzer bulundu $(\mathrm{P}>0.05)$. Sonuç olarak, rakım, THI, yaş ve cinsiyet TOC üzerinde kompleks bir etkiye sahipti.

How to cite this article: Kurt S, Eşki F, Salar S, Sel T, Baştan A: The effect of heat stress on total oxidant capacity in hair goats. Veteriner Hekimler Dernegi Dergisi, 92(1): 24-30, 2021, DOI: 10.33188/vetheder.771696 


\section{Introduction}

Farm animals are exposed to stress which is affecting their production and welfare, depending on environmental factors and management conditions $(1,2)$. The environmental factors such as high ambient temperature and relative humidity can cause heat stress in farm animals $(2,3)$. The heat stress occurs, when the effective temperature of the environment exceeds the animal's comfort temperature $(4,5)$. Temperature humidity index (THI) values of 75 or higher are considered stressful. The values greater than 78 cause excessive stress, and animals cannot maintain thermoregulatory mechanisms (3). It has a multifactorial effect on health, so it is an important source of economic loss, including fertility problems in farm animals (6). Heat stress primarily causes dehydration (7). It also causes biological reactions in the physiological, biochemical, hormonal and haematological functions of animals. Thus, animals try to eliminate or minimize the harmful effects of stress (8). At the same time, these changes lead to disruptions in the homeostasis balance of important metabolites such as antioxidants, prooxidants, insulin, lipids, proteins, cholesterol and glucose (2). Most importantly, it is known that heat stress increases reactive oxygen species (ROS) production (9) which are the most abundant oxidant substances in biological systems (10). Already, oxidant substances are normally produced at moderate levels during the conversion of glucose into the form of adenosine triphosphate (ATP) using oxygen (O2) in mitochondria (11). And under normal conditions, antioxidants substances complete the missing electron of ROS and repair them enzymatically or reduce them into new molecules such as $\mathrm{H} 2 \mathrm{O}$ that is harmless to the body (12). However, heat stress results in the excessive production of free radicals (13). Since it also causes a decrease in the antioxidant defense system, it results in oxidative stress, which can cause tissue pathologies by damaging macromolecules of healthy cells including deoxyribonucleic acid (DNA), lipids and proteins $(2,14)$. Moreover, altitude can affect the antioxidant defense system and lead to oxidative stress. And it is known that high altitude is associated with increased production of free radicals due to low oxygen pressure (15). So, it is understood that heat stress and excessive oxidant production are critical for farm animals. The aim of this study was to investigate the effect of heat stress on total oxidant capacity (TOC) in hair goats of different ages grown at different altitudes in the same season.

\section{Material and Methods}

The study was carried out on 208 hair goats (25 male and 183 female) in 11 different districts (Table 1) of Adana province (Turkey) in the summer season (June, July and August months). All of the goats used in the study were mature and cyclically active animals that reached puberty. Power analysis was taken into account in determining the sample size. The districts were grouped as 0-99 m (Group 1), 100-500 m (Group 2) and higher than $500 \mathrm{~m}$ (Group 3) according to altitude characteristics. Goats were classified into two groups as under 3 years and 4 years or older. Since the sample distribution was chosen randomly, age groups could not be classified according to altitude within themselves. All goats had similar properties, were managed in extensive systems under the same conditions and were clinically healthy including rectal temperature, respiratory, appetite,physical posture and anamnesis. Blood samples $(10 \mathrm{ml})$ were collected from the jugular vein into sterile vacutainer tubes (Hema \& Tube ${ }^{\circledR}$, Italy) containing a clot activator using $18-\mathrm{G}$ needles at the same periods. The blood samples were centrifuged at $3000 \mathrm{xg}$ for 10 minutes, then harvested serums were stored at $-20^{\circ} \mathrm{C}$ until TOC analysis.

\section{Calculation of temperature humidity index (THI):}

THI is a combination of environmental temperature and relative humidity. It is used to assess the risk of heat stress (3). The daily temperature and humidity data were obtained from the meteorological station with the official application. Daily measurements (temperature, humidity) were not made in the farms where the study was conducted because all goats were managed under extensive systems. The THI data of each region were obtained using temperature and relative humidity according to the formula described below (Table 1) (16). And THI values of the time the study was performed in each zone was taken into account. THI data calculated according to the regions are presented in the results section (Table 2). THI levels are considered normal if they are 70 or less, moderate stress if between 75 and 78 , and severe heat stress if they are greater than 78 (3). 
Table 1: Temperature humidity index formula

Tablo 1: Sicaklık nem indeksi formülü

THI $[(1.8 \times \mathrm{T}+32)-[(0.55-0.0055 \times \mathrm{RH}) \times(1.8 \times \mathrm{T}-26.8)]$

Tis the air temperature in ${ }^{\circ} \mathrm{C}$. $\mathrm{RH}$ is the relative humidity in $\%$.

Table 2: The districts where the study was conducted and the calculated THE data

Tablo 2: Çalışmanın yürütüldü̆̆ü ilçeler ve hesaplanan THI değerleri

\begin{tabular}{lll}
\hline Altitude (m) & Districts & THI \\
\hline $0-99$ & Ceyhan & 80 \\
& Yumurtalık & 80 \\
& Yüreğir & 79 \\
İmamoğlu & 78 \\
& Karataş & 81 \\
& Kozan & 78 \\
& Çukurova & 77 \\
$100-500$ & Sariçam & 78 \\
$\geq 501$ & Tufanbeyli & 66 \\
& Pozantı & 75 \\
& Aladă & 78 \\
\hline
\end{tabular}

Total oxidant capacity (TOC) and test principle:

Serum TOC levels were measured using an ELISA device (TECAN, Sunrise ${ }^{\circledR}$ Swiss) and commercial kits (LOT: OK18104O, Rel Assay Diagnostics, Clinical Chemistry Solutions, Gaziantep) based on the method developed by Erel $(17,18)$. The test principle is a colorimetric method, which can be measured spectrophotometrically. It indicates the total amount of oxidant substances in the samples. Hydrogen peroxide is used as a calibrator in this test method (17). The results were expressed as micromolar hydrogen peroxide equivalent per liter $\left(\mu \mathrm{mol} \mathrm{H}_{2} \mathrm{O}_{2}\right.$ Equiv. /L).

\section{Statistical analysis}

All data were analyzed using SPSS 21.0 Windows statistical package program evaluation version. The TOC analyzes of goats in different districts were compared using one-way Anova test. The age and gender groups were evaluated by independent-T test. A P-value less than 0.05 was considered statistically significant. Obtained results were presented as Mean \pm Standard deviation (Mean \pm Std deviation).

\section{Results}

In the present study, it was found that THI levels decreased significantly as altitude increases $(\mathrm{P}<0.001)$. There were severe and moderate heat stress in groups 1 and 2, respectively $(\mathrm{P}<0.001)$. But, there was no heat stress in group $3(\mathrm{P}<0.001)$. Serum TOC levels were significantly lower in group 2 compared to the other two groups $(\mathrm{P}<0.001)$. And, the highest TOC value was measured in group 3 compared to other groups $(\mathrm{P}<0.001)$. It was determined that the 
distribution of age was similar in different THI values according to regions $(p>0.05)$. Serum TOC levels were significantly higher in animals 4 years and older compared to under 3 years old $(\mathrm{P}<0.05)$. It also was observed that male goats were exposed to significantly higher THI than females goats $(\mathrm{P}<0.01)$. TOC levels were similar in male goats compared to female goats $(\mathrm{P}>0.05)$. TOC levels, THI values and other results in groups are shown in Table 3.

Table 3: Effect of THI on serum TOC levels in hair goats. (Mean \pm Std. deviation).

Tablo 3: Kıl keçilerinde THI’nın serum TOC seviyesine etkisi. (Aritmetik Ort. \pm Std. sapma).

\begin{tabular}{ccccccc}
\hline Variables & & $\begin{array}{c}\text { Number of } \\
\text { animals (n) }\end{array}$ & TOC/ $\boldsymbol{\mu m o l} / \mathbf{L}$ & P Value & THI & P Value \\
\hline Altitude & $0-99(\mathrm{G} \mathrm{1)}$ & 89 & $8.733 \pm 4.112$ & & $79.40 \pm 1.105$ & \\
$(\mathrm{~m})$ & $100-500(\mathrm{G} 2)$ & 50 & $6.954 \pm 2.815$ & $<0.001^{\mathrm{a}}$ & $77.86 \pm 0.351$ & $<0.001^{\mathrm{a}}$ \\
& $\geq 501(\mathrm{G} \mathrm{3})$ & 69 & $9.733 \pm 3.526$ & & $72.91 \pm 5.075$ & \\
Age & $<3$ & 69 & $7.762 \pm 2.831$ & $0.018^{\mathrm{b}}$ & $76.91 \pm 4.385$ & 0.935 \\
& $\geq 4$ & 139 & $9.072 \pm 4.103$ & & $76.86 \pm 4.045$ & \\
Gender & Female & 183 & $8.687 \pm 3.832$ & 0.610 & $76.57 \pm 4.302$ & $0.003^{\mathrm{c}}$ \\
& Male & 25 & $8.276 \pm 3.335$ & & $79.16 \pm 1.434$ & \\
\hline
\end{tabular}

TOC: Total oxidant capacity, G 1: Group 1, G 2: Group 2, G 3: Group 3. ${ }^{a} P<0,001 ;{ }^{b} P<0,05 ;{ }^{c} P<0,01$

\section{Discussion and Conclusion}

In the present study, the effects of heat stress, altitude, gender and age on TOC were evaluated in hair goats. It is reported that goats have good tolerance to heat stress due to their thermoregulation ability, and long-haired goats more resistant to heat stress compared to short-haired goats (16). No matter how resistant the farm animals to heat stress, this is considered a major problem for livestock. Because it negatively affects the health and production of farm animals in many ways $(19,20)$. Considering the increasing global temperature $(21)$, the issue becomes more important. It has been reported that environmental temperature and humidity should be evaluated together and heat stress should be monitored according to THI values. Because the effect of ambient temperature on farm animals changes according to the moisture content $(21,22)$. THI levels were used as a heat stress index in this study.

In the present study, the altitude had an effect on THI levels. This was due to the decrease in air temperature and humidity as altitude increases. Teama (14) reported that THI has an effect on oxidative stress. Kumar et al. (23) noticed that oxidative stress increases in goats during the summer season. Similarly, several researchers reported that heat stress has increased the production of oxidant substances $(14,24)$. The overall oxidation status of the body is determined by measuring the TOC level. It represents the sum of all the oxidants substances present in blood serum. It is also defined as reactive oxygen metabolites (17). In our study, it was observed that the THI increased serum TOC levels in group 1 when compared to group 2. However, there was no positive correlation between THI and TOC in group 3 compared to other groups. This situation showed that THI did not have a similar effect on TOC in all groups. Although THI value was also lower in group 3 according to the other groups, the TOC value was measured higher. This situation can be associated with the altitude. Because it was reported that exposure to high altitude results in the increase of ROS production by the mitochondrial metabolism of cells due to differences in oxygen pressure (25). Similarly, Dosek et al. (26) reported that at high altitude, oxygen pressure decreases and production of reactive nitrogen and oxygen species increases, causing oxidative stress. It has also been declared that the degree of oxidative stress is associate with the level of altitude. Moreover, it was revealed that exposure to high altitude could reduce the activity of antioxidant systems (26). So, it is thought that the increase of the TOC levels of group 3 was caused by the high altitude and low oxygen pressure of the districts. It is thought that these results are very important for goat breeding because goat farming is common at high altitudes. Furthermore, antioxidant activity should be investigated in goats 
raised at different altitudes. But, antioxidant levels were not detected in this study. Because our main aim was to determine the effect of THI and altitude on TOC levels. The major findings of this study are that the altitude and THI are significant determinants for TOC levels. There is no specific study on the effect of gender and age on TOC levels in hair goats under heat stress. Chaturvedi and Kataria (27) reported that age and gender have affected concentrations of some antioxidant substances at different ambient temperatures in Marwari goats. Also, it was revealed that levels of antioxidant substances were higher in male goats than female goats and antioxidant levels increased with age in all groups (27). On the other hand, it has been reported that there is a positive relationship between biological aging and oxidant production in some animal models $(28,29)$. Similarly, in our study, aging was linked to an increase in oxidant generation in hair goats. This is thought to result from an increased ROS accumulation in aging organs. Balci et al. (30) reported that gender difference has an effect on adaptation process to changes in antioxidant capacity. Oxidative stress risk is higher in males compared to females (31). And Razmara et al. (32) informed that estrogen increases the antioxidant activity in the mitochondria. According to this information, TOC level is expected to be lower in female goats than in male goats. In this study, male animals were exposed to higher ambient THI levels than females, but this did not affect the TOC level. Therefore, it was thought that male hair goats were more resistant to heat stress in terms of TOC levels.

In conclusion, THI levels had an effect on TOC in hair goats. However, at high altitude TOC increased despite low THI. Age and gender also affected the TOC level. So, studies investigating the effect of THI on oxidant capacity in hair goats should also take into account age, gender and altitude.

\section{Conflict of Interest}

The author declared no conflict of interest.

\section{Funding}

No funding.

\section{Authors' Contributions}

Idea/Concept: Serdal KURT, Funda EŞKİ

Experiment design:Serdal KURT, Funda EŞKI, Ayhan BAŞTAN, Seçkin SALAR

Supervision/Consultancy: Funda EŞKİ, Ayhan BAŞTAN, Seçkin SALAR

Data collecting: Funda EŞKİ, Serdal KURT

Data analysis and interpretation: Tevhide SEL

Literature research: Serdal KURT, Funda EŞKI

Writing the article: Serdal KURT, Funda EŞKI

Critical review: Funda EŞKİ, Ayhan BAŞTAN, Seçkin SALAR

\section{Ethical Approval}

This study was carried out with the permission of the Cukurova University, Local Ethics Committee of Ceyhan Faculty of Veterinary Medicine (Decision Date and Number: 12.12.2018 and 1/11).

\section{References}

1. Blokhuis HJ, Hopster H, Geverink NA, Korte SM, Van Reenen CG (1988): Studies of stress in farm animals. Comp Haematol Int, 8(2), 94-101.

2. Belhadj Slimen I, Najar T, Ghram A, Abdrrabba M (2016): Heat stress effects on livestock: molecular, cellular and metabolic aspects: a review. J Anim Physiol An N, 100(3), 401-412.

3. Silanikove N (2000): Effects of heat stress on the welfare of extensively managed domestic ruminants. Livest Prod Sci, 67(1-2), 1-18. 
4. Al-Tamimi HJ (2007): Thermoregulatory response of goat kids subjected to heat stress. Small Ruminant Res, 71(13), 280-285.

5. Srikandakumar A, Johnson EH, Mahgoub O (2003): Effect of heat stress on respiratory rate, rectal temperature and blood chemistry in Omani and Australian Merino sheep. Small Ruminant Res, 49(2), 193-198.

6. Das R, Sailo L, Verma N, Bharti P, Saikia J (2016): Impact of heat stress on health and performance of dairy animals. Vet world, 9(3), 260-268.

7. Maloiy GMO, Kanui TI, Towett PK, Wambugu SN, Miaron JO, Wanyoike MM (2008): Effects of dehydration and heat stress on food intake and dry matter digestibility in East African ruminants. Comp Biochem Phys A, 151(2), 185-190.

8. Ribeiro MN, Ribeiro NL, Bozzi R, Costa RG (2018): Physiological and biochemical blood variables of goats subjected to heat stress: a review. J Appl Anim, 46(1), 1036-1041.

9. Del Vesco AP, Gasparino E (2013): Production of reactive oxygen species, gene expression, and enzymatic activity in quail subjected to acute heat stress. JAS, 91(2), 582-587.

10. Abuelo A, Hernaandez J, Benedito JL, Castillo C (2015): The importance of the oxidative status of dairy cattle in the periparturient period: revisiting antioxidant supplementation. J Anim Physiol An N, 99(6), 1003-1016.

11. Mavangira V, Sordillo LM (2018): Role of lipid mediators in the regulation of oxidative stress and inflammatory responses in dairy cattle. Res Vet Sci, 116(1), 4-14.

12. Puppel K, Kapusta A, Kuczyńska B (2015): The etiology of oxidative stress in the various species of animals: a review. J Sci Food Agric, 95(11), 2179-2184.

13. Kumar S, Ajeet K, Meena K (2011): Effect of heat stress in tropical livestock and different strategies for its amelioration. J Stress Physiol Biochem, 7(1), 45-54.

14. Teama FEI (2018) (2004): Evaluation of some oxidative-stress and antioxidant markers in goats during estrous cycle under Egyptian environmental conditions. Rev bras zootecn, 47, 1-8.

15. Bakonyi T, Radak Z (2004): High altitude and free radicals. JJSM, 3(2), 64.

16. Salama AAK, Caja G, Hamzaoui S, Badaoui B, Castro-Costa A, Facanha DAE, Bozzi R (2014): Different levels of response to heat stress in dairy goats. Small Ruminant Res, 121(1), 73-79.

17. Erel O (2005): A new automated colorimetric method for measuring total oxidant status. Clin Biochem, 38(12), 1103-1111.

18. Karapehlivan M, Kaya I, Sag A, Akin S, Ozcan A (2013): Effects of early and late lactation period on plasma oxidant/antioxidant balance of goats. Kafkas Univ Vet Fak Derg, 19(3), 529-533.

19. Alam MM, Hashem MA, Rahman MM, Hossain MM, Haque MR, Sobhan Z, Islam MS (2011): Effect of heat stress on behavior, physiological and blood parameters of goat. Progress Agric, 22(1-2), 37-45.

20. Habeeb AGA, EL-Tarabany A, Atta M (2018): Negative effects of heat stress on growth and milk production of farm animals. Res j Animal Hus Dairy Sci, 2(1), 1-12.

21. Avendano-Reyes L (2012): Heat stress management for milk production in arid zones. 165-184. In: Chaiyabutr N (Ed), Milk production-An up-to-date overview of animal nutritio, management and health. IntechOpen, London.

22. De Rensis F, Garcia-Ispierto I, López-Gatius F (2015): Seasonal heat stress: Clinical implications and hormone treatments for the fertility of dairy cows. Theriogenology, 84(5), 659-666.

23. Kumar M, Jindal R, Nayyar S (2011): Influence of heat stress on antioxidant status in Beetal goats. IJSR, 17(2), 178-181.

24. Sivakumar AVN, Singh G, Varshney VP (2010): Antioxidants supplementation on acid base balance during heat stress in goats. Asian-Australasian J Anim Sci, 23(11), 1462-1468.

25. Bakonyi T, Radak Z (2004): High altitude and free radicals. J Sport Sci Med, 3(2), 64-69.

26. Dosek A, Ohno H, Acs Z, Taylor AW, Radak Z (2007): High altitude and oxidative stress. Resp Physiol Neurobi, 158(2-3), 128-131.

27. Chaturvedi M, Kataria N (2013): Assessment of role of antioxidants in erythrocytes of Marwari goat from arid tracts in India to evaluate oxidative stress. Elba Bioflux, 5(1), 1-8. 
28. Zhang HJ, Xu L, Drake VJ, Xie L, Oberley L W, Kregel KC (2003): Heat-induced liver injury in old rats is associated with exaggerated oxidative stress and altered transcription factor activation. FASEB J, 17(15), 2293-2295.

29. Kregel KC, Zhang HJ (2007): An integrated view of oxidative stress in aging: basic mechanisms, functional effects, and pathological considerations. Am J Physiol Regul Integr Comp Physiol, 292(1), 18-36.

30. Balci SS, Pepe H, Güney S, Özer Ç, Revan S (2012): Effects of gender, endurance training and acute exhaustive exercise on oxidative stress in the heart and skeletal muscle of the rat. Chin J Physiol, 55(4), 236-44.

31. Wang X, Desai K, Juurlink BHJ, De Champlain J, Wu L (2006): Gender-related differences in advanced glycation endproducts, oxidative stress markers and nitric oxide synthases in rats. Kidney Int, 69(2), 281-287.

32. Razmara A, Duckles SP, Krause DN, Procaccio V (2007): Estrogen suppresses brain mitochondrial oxidative stress in female and male rats. Brain Res, 1176, 71-81. 